\title{
The Use of Computer Simulation to Compare Student Performance in Traditional Versus Distance Learning Environments
}

\author{
Retta Sweat Guy and Millicent Lownes-Jackson \\ Tennessee State University, Nashville, Tennessee, USA \\ rquy@tnstate.edu mlownes@tnstate.edu
}

\begin{abstract}
Simulations have been shown to be an effective tool in traditional learning environments; however, as distance learning grows in popularity, the need to examine simulation effectiveness in this environment has become paramount. A casual-comparative design was chosen for this study to determine whether students using a computer-based instructional simulation in hybrid and fully online environments learned better than traditional classroom learners. The study spans a period of 6 years beginning fall 2008 through spring 2014. The population studied was 281 undergraduate business students self-enrolled in a 200-level microcomputer application course. The overall results support previous studies in that computer simulations are most effective when used as a supplement to face-to-face lectures and in hybrid environments.
\end{abstract}

Keywords: computer simulation, traditional classroom, distance learning, hybrid, face-to-face teaching, lectures and demonstrations, student performance

\section{Introduction}

Innovative advances in technology have introduced a variety of tools to enhance learning in higher education. Among these, computer simulations have been used (1) to support a variation of cognitive learning styles, (2) to facilitate higher-order thinking and problem solving skills, and (3) to augment differential, collaborative, and mastery learning (Koh et al., 2010). A widely acceptable tool for teaching and learning, computer simulations combines visual and interactive learning experiences, promotes application of knowledge, and provides a simplified representation of real-world systems (Eskrootchi \& Oskrochi, 2010; Nishikawa \& Jaeger, 2011).

Scholars ascertain that guided discovery, deliberate practice, and engagement in active learning by means of computer simulation leads to enhanced performance and retention of concepts (Udo \& Etiubon, 2011; West \& Veenstra, 2012). Additionally, study reports cite immediate feedback,

Material published as part of this publication, either on-line or in print, is copyrighted by the Informing Science Institute. Permission to make digital or paper copy of part or all of these works for personal or classroom use is granted without fee provided that the copies are not made or distributed for profit or commercial advantage AND that copies 1) bear this notice in full and 2) give the full citation on the first page. It is permissible to abstract these works so long as credit is given. To copy in all other cases or to republish or to post on a server or to redistribute to lists requires specific permission and payment of a fee. Contact Publisher@InformingScience.org to request redistribution permission. skill acquisition, and self-directed learning as the most prevalent reasons for computer simulation use across disciplines (Bai \& Fusco, 2011; Koenig, Iseli, Wainess, \& Lee, 2013).

In earlier literature, Brown, Collins and Duguid (1989) argued that "classroom activities lack the contextual features of real-life problem-solving situations and therefore weaken the ability of students 
to transfer and apply knowledge from classroom to work environments" (p. 34). Moreover, several studies conclude that in order to facilitate transfer, authentic-like tasks are necessary to promote effective learning and workplace relevance (Koenig et al., 2013; Muir, Allen, Rayner, \& Cleland, 2013; Rackaway \& Goertzen, 2008). When used as an instructional method, Rogers (2011) contends that computer simulation bridges the gap between reality and abstract knowledge. Eskrootchi and Oskrochi (2010) believe that computer simulations provide connections to real-world contexts that positively impact student learning.

In sum, proponents affirm that computer simulations promote student interest and involvement, foster retention of information, and offers opportunities for affective and behavioral learning (Alexe, 2013; Koenig et al., 2013; Muir et al., 2013; Sauter, Uttal, Rapp, Downing, \& Jona, 2013). Furthermore, those in favor of computer simulation use in higher education contend that through repeated practice and immediate feedback, transfer of knowledge, skills, and abilities from classroom to real world environments is enhanced (Alexe, 2013; Rackaway \& Goertzen, 2008).

Despite support for computer simulation use in higher education, critics point out that:

- it impedes further development of students' interpersonal skills due to the lack of face-toface interactions between and among the instructor and students, respectively (Asal \& Blake, 2006);

- it has pronounced pedagogical drawbacks as there is a lack of empirical findings linking its use to positive learning outcomes (Kahn \& Perez, 2009; Wheeler, 2006) and methodologically speaking, much of the research supporting such findings lack a high standard of rigor (Frederking, 2005; Shellman, 2006); and

- it perpetuates random guessing and therefore is not a valid or reliable predictor of student performance (Teach \& Patel, 2007; Wolfe \& Luethge, 2003).

Computer simulations have primarily been used to augment the learning process in traditional, face-to-face environments (Rutten, Van Jooloingen, \& Van der Veen, 2012), however, the rapid growth of distance education has prompted practitioners and researchers to re-examine delivery structures and the role of technology as a means to integrate and enhance the distance learning experience (Rogerson-Revell, Nie, \& Armellini, 2012). Still, few studies have been conducted that explore how different delivery methods of instruction impact students' learning with regard to computer simulations as most researchers are only concerned with the overall medium effects in comparison with the traditional instruction. For this reason, the purpose of the current study is to investigate the impact of computer simulations on student performance as used in alternative methods of delivery. The following research questions were postulated for this study:

1. Are there significant differences in student performance when comparing the traditional format with the hybrid method of instruction augmented with computer simulation?

2. Are there significant differences in student performance when comparing the traditional format with the fully online method of instruction using computer simulation?

3. Are there significant differences in student performance when comparing the hybrid format augmented with computer simulation with the fully online method of instruction using computer simulation?

\section{Literature Review}

There have been a sufficient number of experimental studies to examine the instructional value of computer simulations. The use of computer simulations for supporting classroom teaching has interested educators and researchers in many fields of study. In many instances, researchers used 
instructional methods, such as traditional lecture and demonstration, hybrid, and fully online course designs to compare and assess the value of computer simulations. The research results from these studies were conflicting.

\section{Comparison Studies of Simulations and Traditional Learning}

Alexe (2013) examined the use of computer simulation to improve foreign language abilities of 30 students enrolled at Technical University of Civil Engineering Bucharest. The study methodology encompassed 3 components in which (1) prior knowledge was assessed, (2) new context for vocabulary acquisition was presented, and (3) acquired language skills were evaluated. The subjects were randomly assigned to a control group and an experimental group. Students in the control group were taught foreign language vocabulary using traditional instructional methods while those in the experimental group were given access to a computer-based simulation. The results revealed that students' foreign language skills and abilities were enhanced in both groups, however, the experimental group learned at a much faster pace and with greater ease.

Secomb, Mckenna, and Smith (2012) sought to provide evidence of the effectiveness of simulation activities on the clinical decision-making abilities of 58 third-year undergraduate nursing students at 3 universities located in Australia. Students in the experimental group received access to a clinical decision-making simulation activity while a clinical instructor facilitated lecture and demonstrations in a traditional skills laboratory environment with the control group. The learning environment preferences inventory was used to test and compare cognitive abilities of students in both groups. The test scores revealed a non-significant difference in student performance between groups. In a similar study, West and Veenstra (2012) documented the academic performances of 226 second-year physiology students of which 112 were provided access to computer-simulated practicals while 114 were assigned to a traditional hands-on laboratory with demonstrators present. Again, no significant differences were found when comparing the performances of students in both groups.

Udo and Etibuon (2011) conducted a study in which a pre-test - post-test experimental design was used to determine the effectiveness of computer simulation on student achievement in a chemistry course compared with guided-discovery and traditional expository teaching methods. A sample of 89 students were randomly assigned to 3 treatment groups in which all course sections were taught the same concepts under chemical combination. Group 1 was taught using a computer-based science simulation, group 2 was taught using guided-discovery method, and group 3 was taught using the traditional instructor-centered expository approach. The authors concluded that the computer-based science simulation had a greater enhancing effect on students' performance than the traditional expository method, but was comparable with guided-discovery approach. An earlier study conducted by Udo (2010) yielded similar results.

Bobot (2010) conducted a study in which he compared the effectiveness of two different sales management course designs at Negocia Business School in Paris, France. The first design was taught in the traditional class format with case studies while the second design was exposed to a combination of computer simulations and case studies. The study involved 150 students randomly assigned to six course sections, all of which were taught by the same instructor with the same course content. The results confirmed that both course designs produced statistically equivalent learning outcomes.

The aim of the study conducted by Koh et al. (2010) was to investigate the impact of simulationbased learning as an instructional strategy on student performance. Study participants included 114 second-year engineering students from the School of Engineering in Temasek Polytechnic. The students were randomly distributed in five classes, two of which were randomly assigned to the control group and the other three classes to the experimental group. The control group re- 
ceived two-hour lectures while the experimental group received 1.5 hours in lecture and a halfhour of simulation-based learning session. The results show that the test scores of the experimental group were significantly higher than those of the control group. Additionally, in studies conducted by Mkpanang (2010) and Neumann, Hood, and Neumann (2010) the integration of computer simulations into traditional classroom lectures proved to be a positive addition in regard to student performance, engagement, and motivation.

In earlier studies, Ackermann (2009) reported that when comparing knowledge acquisition and retention of CPR skills between groups exposed to simulation and another without this treatment, both groups' knowledge retention decreased. However, the participants who experienced the simulation had better retention than those who did not. Kardong-Eddren, Anderson, and Michaels (2007) reported the results of their research in which there were no significant differences in preor post-test scores between students receiving lecture only and those accessing simulation only in a nursing management of congestive heart failure course. Similarly, Nishikawa and Jaeger (2011) conducted a randomized experiment where participants were assigned to a traditional classroom lecture or a class using a computer simulation. Student performance was evaluated by a posttest and a delayed post-test. Results show strong evidence that computer simulations are as effective as traditional classroom lectures in the short run and produce better concept retention in the long run.

\section{Comparison Studies of Simulations and Distance Learning}

Simulations have been shown to be an effective tool in traditional learning environments (Alexe, 2013; Bobot, 2010; Secomb et al., 2012; Udo \& Etibuon, 2011; West \& Veenstra, 2012); however, as distance learning grows in popularity, the need to examine simulation effectiveness in this environment has become paramount. This paper reviews the literature on the effectiveness of simulation use in fully online environments - a setting in which instruction and content are delivered over the Internet (Evans \& Fan, 2002; Ko \& Rossen, 2001) and hybrid modalities - a combination of traditional face-to-face instruction and online learning (Amaral \& Shank, 2010).

Otamendi and Doncel (2013) set out to teach an online course, incorporated with a Web-based simulation, which mirrored characteristic of traditional classroom teaching. The face-to-face classroom sessions included traditional lectures along with the experimental exercise using the simulation while the online class was conducted using the Web-based simulation along with a link to a videoconference that included a chat. Additionally, students in the online session were granted access to recorded videos of the face-to-face classroom lectures. The authors concluded that learning goals were attained and a high-level of satisfaction was exhibited among students in both groups. The integration of technology played an integral role in the acquisition of knowledge for both the traditional and online classroom, whereas the former benefitted from the technology and the role play actions associated with the Web-based simulation while the latter gained from video recordings as it provided a traditional classroom lecture atmosphere.

Science courses with labs are well suited for computer simulation use to illustrate real world laboratory experiences. For instance, Sauter et al. (2013) investigated learning by comparing students' experiences with a remote lab and a simulation. As described by the authors:

Remote labs are computer-mediated laboratory experiences that allow students to access real experimental devices online such as oscilloscopes, mass spectrometers, or Geiger counters whereas simulations do not provide access to real experimental devices but instead simulate data using computational models. (p. 38)

Study participants included 123 undergraduate students at Northwestern University, of which 83 were freshman and the remainder included a mix of sophomores, juniors, and seniors. Participants assigned to the remote lab condition first viewed a live webcam feed of the Geiger counter per- 
forming the experiment then accessed the Radioactivity iLab website to conduct the same experiment. The simulation condition viewed a recording of a webcam feed performing a similar experiment then accessed an identical Web interface but received simulated data based on computational models. Sauter et al. (2013) concluded that learning took place in both groups; however, students in the remote lab were observed as being more engaged. In earlier reviews, Blake and Scanlon (2007), Sahin (2006), and Hennessy (2006) supported the use of simulations to facilitate distance education laboratories.

Mosalanejad, Shahsavari, Sobhanian, and Dastpak (2012) conducted a quasi-experimental study to determine the effectiveness of computer-based simulations in a virtual environment. The participants included 86 nursing students randomly divided into 2 groups. Students in group 1 were taught theory and practical content by traditional methods (lecture and demonstrations) while the same instructor taught students in group 2 the same content in a virtual network environment (video systems and virtual simulation). The authors found a significant difference in achievement scores between the two groups. Those students taught by virtual methods received higher mean scores in comparison to the group taught by traditional methods.

Neumann, Neumann, and Hood (2011) examined the effectiveness of combining different modes of delivery integrated with computer simulations. Study participants included a stratified random sample of 38 students in a first year statistics course. The course instructor adopted a blended learning approach, also known as hybrid learning by delivering multimedia presentations during face-to-face lectures, providing online access to lecture notes, and using computer-based simulations of statistical concepts. The breakdown of the course consisted of 2 hours of lecture followed by a 1-hour tutorial course that incorporated group exercises and computer simulation activities. The authors reported that enhanced learning, active engagement, and increased motivation were realized as a result of the hybrid learning environment. Similarly, Decker et al. (2010) suggest that a combination of simulations, lectures and demonstrations incorporated with multiple learning styles promotes critical thinking, reflection, and knowledge creation.

As noted in earlier studies, Cameron (2003), Sharp and Hall (2000), and Granland, Bergland, and Eriksson (2000) report greater performance gains with students enrolled in distance learning courses integrated with computer simulations compared to those enrolled in traditional face-toface learning environments. However, Dean and Webster (2000) report opposing results indicating that the use of computer simulations in distance education does not promote transfer of knowledge to a greater degree than other methodologies.

\section{Methodology}

The current study was conducted at Tennessee State University (TSU), a comprehensive, urban, coeducational, land-grant university located in Nashville. A constituent institution of the Tennessee Board of Regents, TSU was founded in 1912 and currently serves a growing population of nearly 9,000 students.

The current study encompasses students from the College of Business at Tennessee State University. All programs offered in the College are accredited through the Association to Advance Collegiate Schools of Business (AACSB International), a distinguished accrediting body for business programs in higher education. The College boasts a student population of 879 of which $76 \%$ are African American, 19\% are White, 4\% Asian, and 1\% Hispanic, Additionally, the majority are traditional (67\%) versus non-traditional (33\%) students, with 55\% male and $45 \%$ female.

The study spans a period of 6 years beginning fall 2008 through spring 2014. The population studied was 281 undergraduate business students self-enrolled a 200-level microcomputer application course, a requirement for all business majors. The instructor, who holds a doctorate in In- 
structional Systems Design and has extensive pedagogical research in the area of computing, taught all courses used in this study.

A casual-comparative design was chosen for this study to determine whether students using a computer-based instructional simulation in hybrid and fully online environments learned better than traditional classroom learners. There were nine sections of this course taught during the study period, of which, three sections were designated as the control group, three were designated the experimental-hybrid group, and three were designated as the experimental-fully online group.

Students in the control-traditional group received lectures and demonstrations from the instructor for each application feature (i.e., Microsoft Word, Excel, PowerPoint, and Access). Students in the experimental-hybrid group received lectures supplemented with SIMNET, a computer-based instructional simulation, while the experimental-fully online group was exposed to SIMNET and PowerPoint slides only, without the benefit of lecture.

SIMNET is a fully simulated version of the Microsoft Office applications (see Figure 1) and was used to present each skill and topic in the following modes:

- Teach Me: combines instructional text, graphics, and interactivity to present each skill.

- Show Me: Uses animation with audio narration to show how the skill is implemented.

- Let Me Try: Allows students to apply and practice what they have learned on their own to master the learning objective.

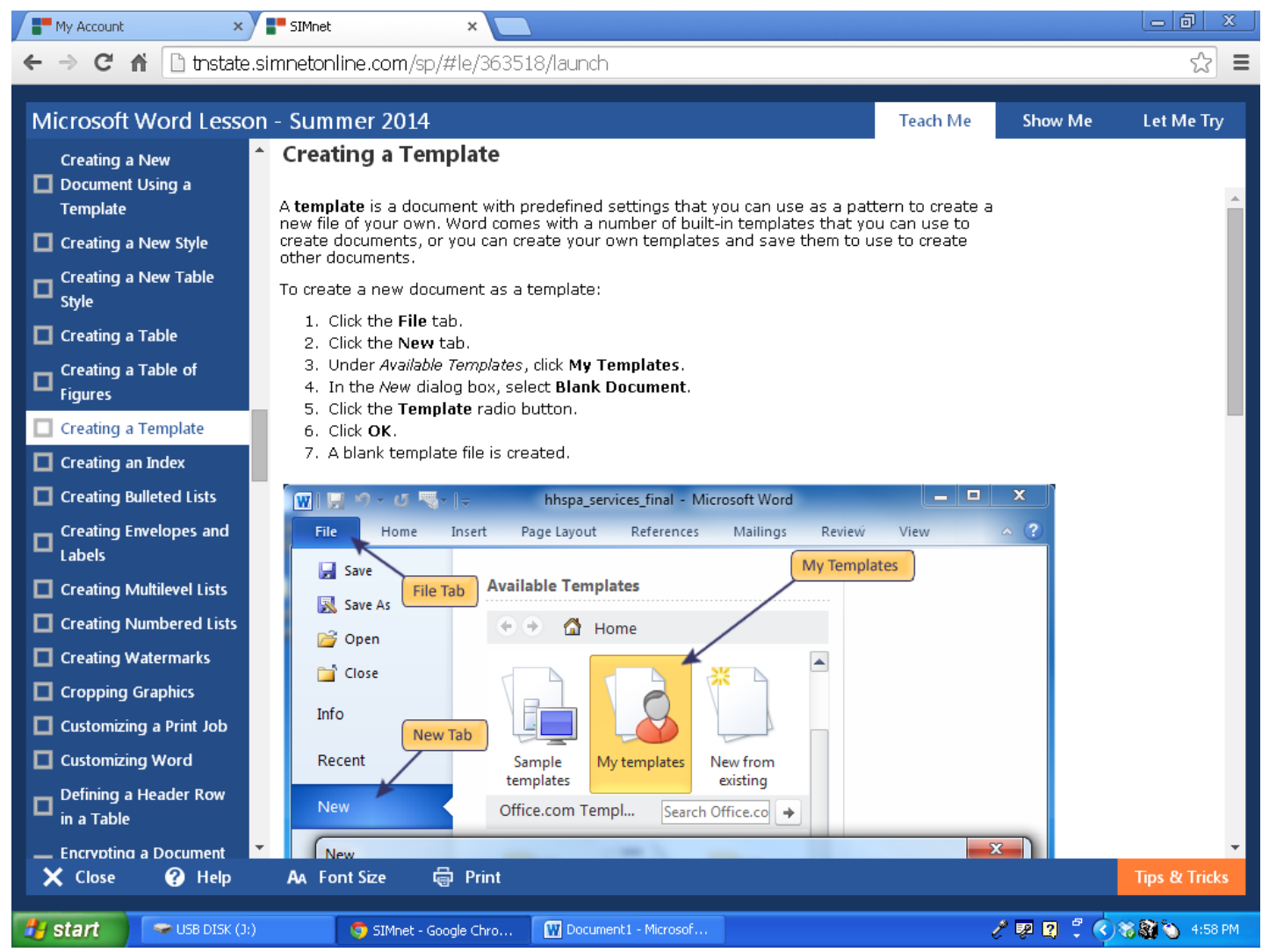

Figure 1: SIMNET

In each instance, students were challenged to use their knowledge and skills of Microsoft Office Suite and accordingly were required to complete projects such as formatting business and financial documents, organizing data, designing marketing documents, setting up databases and creat- 
ing promotional presentations. Students were also required to analyze real-world business problems and then apply appropriate media and strategy solutions, utilizing formatting tools and graphics to enhance document design, layout, functionality, and appearance.

Learning objectives for each software application along with an abbreviated version of the rubric that defines each level of competency by grade is presented in Table 1.

\begin{tabular}{|c|c|c|c|c|c|}
\hline & \multicolumn{5}{|c|}{ Level of Competency by Grade } \\
\hline Learning Objectives & $\mathrm{A}$ & $\mathrm{B}$ & $\mathrm{C}$ & $\mathrm{D}$ & $\mathrm{F}$ \\
\hline \multicolumn{6}{|l|}{ Microsoft Word } \\
\hline $\begin{array}{l}\text { Format text and paragraphs } \\
\text { Format documents } \\
\text { Work with tables and graphics } \\
\text { Work with references and mailings }\end{array}$ & $\begin{array}{l}\text { All objec- } \\
\text { tives were } \\
\text { met }\end{array}$ & $\begin{array}{l}\text { Most } \\
\text { were } \\
\text { met }\end{array}$ & $\begin{array}{l}\text { Half } \\
\text { were } \\
\text { met }\end{array}$ & $\begin{array}{l}\text { Less than } \\
\text { half were } \\
\text { met }\end{array}$ & $\begin{array}{l}\text { No objec- } \\
\text { tives were } \\
\text { met }\end{array}$ \\
\hline \multicolumn{6}{|l|}{ Microsoft Excel } \\
\hline $\begin{array}{l}\text { Use formulas and functions } \\
\text { Format worksheets } \\
\text { Add charts and analyze data }\end{array}$ & $\begin{array}{l}\text { All objec- } \\
\text { tives were } \\
\text { met }\end{array}$ & $\begin{array}{l}\text { Most } \\
\text { were } \\
\text { met }\end{array}$ & $\begin{array}{l}\text { Half } \\
\text { were } \\
\text { met }\end{array}$ & $\begin{array}{l}\text { Less than } \\
\text { half were } \\
\text { met }\end{array}$ & $\begin{array}{l}\text { No objec- } \\
\text { tives were } \\
\text { met }\end{array}$ \\
\hline \multicolumn{6}{|l|}{ Microsoft PowerPoint } \\
\hline $\begin{array}{l}\text { Add content to slides } \\
\text { Format presentations } \\
\text { Manage and deliver presentations }\end{array}$ & $\begin{array}{l}\text { All objec- } \\
\text { tives were } \\
\text { met }\end{array}$ & $\begin{array}{l}\text { Most } \\
\text { were } \\
\text { met }\end{array}$ & $\begin{array}{l}\text { Half } \\
\text { were } \\
\text { met }\end{array}$ & $\begin{array}{l}\text { Less than } \\
\text { half were } \\
\text { met }\end{array}$ & $\begin{array}{l}\text { No objec- } \\
\text { tives were } \\
\text { met }\end{array}$ \\
\hline \multicolumn{6}{|l|}{ Microsoft Access } \\
\hline $\begin{array}{l}\text { Work with tables } \\
\text { Work with forms and reports } \\
\text { Use queries and organize information }\end{array}$ & $\begin{array}{l}\text { All objec- } \\
\text { tives were } \\
\text { met }\end{array}$ & $\begin{array}{l}\text { Most } \\
\text { were } \\
\text { met }\end{array}$ & $\begin{array}{l}\text { Half } \\
\text { were } \\
\text { met }\end{array}$ & $\begin{array}{l}\text { Less than } \\
\text { half were } \\
\text { met }\end{array}$ & $\begin{array}{l}\text { No objec- } \\
\text { tives were } \\
\text { met }\end{array}$ \\
\hline
\end{tabular}

Additionally, the following represents the grading scale used for all course sections:
A (90-100) Work of excellence quality
B (80-89) Work of good quality
C (70-79) Work of satisfactory quality
D (60-69) Work of poor quality
$\mathrm{F}$ (below 60) Failure to meet the minimum standards 


\section{Findings}

Variably different from the reviews discussed previously, the current study investigates the impact of computer simulations on student performance as used in alternative methods of delivery (e.g., traditional, hybrid, and fully online).

Grade averages for each software application projects were analyzed to determine the impact of a computer-based instructional simulation on student learning. First, the data was analyzed using descriptive statistics for which Statistical Package for Social Sciences (SPSS) was used with the significance level set at a $=0.05$. Secondly, a series of one-way ANOVA and Scheffe post-hoc tests were run to compare mean differences between delivery methods/SIMNET use and student performance for each Microsoft application and grade averages.

Descriptive statistics for Microsoft Word revealed that the Hybrid-Simulation group $(M=4.06)$ outperformed both the Traditional group $(\mathrm{M}=3.61)$ and the Online-Simulation group $(\mathrm{M}=2.89)$ while all three groups had similar standard deviations $(1.63,1.76$, and 1.80 respectively). The ANOVA analysis in Table 2 shows that the p-value (.000) is less than 0.05 , therefore, the results indicate that a statistically significant difference was found between the group means. Based on the aforementioned results, the Scheffe post hoc test was run to determine which specific groups differ significantly from one another with regard to student performance on the Microsoft Word application. As displayed in Table 3, a statistically significant difference was found in student performance when comparing the Online-Simulation group to both the Traditional (.025) and Hybrid-Simulation (.000) groups; however, there were no statistically significant differences between the traditional and hybrid groups (.176).

\begin{tabular}{|l|r|r|r|r|r|}
\hline \multicolumn{7}{|c|}{ Table 2: Microsoft Word-ANOVA } \\
\hline & $\begin{array}{c}\text { Sum of } \\
\text { Squares }\end{array}$ & \multicolumn{1}{c|}{ df } & Mean Square & \multicolumn{1}{c|}{ F } & Sig. \\
\hline Between Groups & 58.350 & 2 & 29.175 & 9.751 & .000 \\
\hline Within Groups & 831.764 & 278 & 2.992 & & \\
\hline Total & 890.114 & 280 & & & \\
\hline
\end{tabular}

\begin{tabular}{|c|c|c|c|c|c|c|}
\hline \multicolumn{7}{|c|}{ Table 3: Microsoft Word-Multiple Comparisons } \\
\hline \multirow[b]{2}{*}{$\begin{array}{l}\text { Method of } \\
\text { Delivery }\end{array}$} & \multirow[b]{2}{*}{$\begin{array}{l}\text { Method of } \\
\text { Delivery }\end{array}$} & \multirow[b]{2}{*}{$\begin{array}{c}\text { Mean } \\
\text { Difference }\end{array}$} & \multirow[b]{2}{*}{$\begin{array}{l}\text { Std. } \\
\text { Error }\end{array}$} & \multirow[b]{2}{*}{ Sig. } & \multicolumn{2}{|c|}{$95 \%$ Confidence Interval } \\
\hline & & & & & $\begin{array}{l}\text { Upper } \\
\text { Bound }\end{array}$ & $\begin{array}{l}\text { Lower } \\
\text { Bound }\end{array}$ \\
\hline \multirow[t]{2}{*}{ Traditional } & Hybrid-Simulation & -.449 & .240 & .176 & -1.04 & .14 \\
\hline & Online-Simulation & $.719(*)$ & .264 & .025 & .07 & 1.37 \\
\hline \multirow[t]{2}{*}{ Hybrid-Simulation } & Traditional & .449 & .240 & .176 & -.14 & 1.04 \\
\hline & Online-Simulation & $1.168(*)$ & .265 & .000 & .52 & 1.82 \\
\hline \multirow[t]{2}{*}{ Online-Simulation } & Traditional & $-.719(*)$ & .264 & .025 & -1.37 & -.07 \\
\hline & Hybrid-Simulation & $-1.168(*)$ & .265 & .000 & -1.82 & -.52 \\
\hline
\end{tabular}

*The mean difference is significant at the .05 level. 
Similarly to the Word Application, descriptive statistics for Microsoft Excel revealed that the Hybrid-Simulation group ( $\mathrm{M}=4.14)$ outperformed both the Traditional group ( $\mathrm{M}=3.40)$ and the Online-Simulation group $(\mathrm{M}=2.82)$ while all three groups had similar standard deviations $(1.57$, 1.73 , and 1.79 respectively). The ANOVA analysis in Table 4 shows that the p-value (.000) is less than 0.05 , therefore, the results indicate that a statistically significant difference was found between the group means. The Scheffe post hoc test revealed a statistically significant difference comparing the performance of students in the Hybrid-Simulation group to both the Traditional $(\mathrm{p}=.008)$ and Online-Simulation $(\mathrm{p}=.000)$ groups (see Table 5$)$; however, there were no statistically significant differences between the Traditional and Online-Simulation groups $(p=0.82)$.

\begin{tabular}{|l|r|r|r|r|r|}
\hline \multicolumn{7}{|c|}{ Table 4: Microsoft Excel-ANOVA } \\
\hline & $\begin{array}{c}\text { Sum of } \\
\text { Squares }\end{array}$ & \multicolumn{1}{c|}{$\mathrm{df}$} & Mean Square & \multicolumn{1}{c|}{ F } & \multicolumn{1}{c|}{ Sig. } \\
\hline Between Groups & 76.160 & 2 & 38.080 & 13.333 & .000 \\
\hline Within Groups & 793.982 & 278 & 2.856 & & \\
\hline Total & 870.142 & 280 & & & \\
\hline
\end{tabular}

\begin{tabular}{|c|c|c|c|c|c|c|}
\hline \multicolumn{7}{|c|}{ Table 5: Microsoft Excel-Multiple Comparison } \\
\hline $\begin{array}{l}\text { Method of Deliv- } \\
\text { ery }\end{array}$ & $\begin{array}{l}\text { Method of Deliv- } \\
\text { ery }\end{array}$ & $\begin{array}{c}\text { Mean } \\
\text { Difference }\end{array}$ & Std. Error & Sig. & \multicolumn{2}{|c|}{ 95\% Confidence Interval } \\
\hline & & $\begin{array}{l}\text { Lower } \\
\text { Bound }\end{array}$ & $\begin{array}{l}\text { Upper } \\
\text { Bound }\end{array}$ & $\begin{array}{l}\text { Lower } \\
\text { Bound }\end{array}$ & Upper Bound & Lower Bound \\
\hline Traditional & $\begin{array}{l}\text { Hybrid- } \\
\text { Simulation }\end{array}$ & $-.736\left(^{*}\right)$ & .234 & .008 & -1.31 & -.16 \\
\hline & Online-Simulation & .578 & .258 & .082 & -.06 & 1.21 \\
\hline Hybrid-Simulation & Traditional & $.736(*)$ & .234 & .008 & .16 & 1.31 \\
\hline & Online-Simulation & $1.314(*)$ & .259 & .000 & .68 & 1.95 \\
\hline Online-Simulation & Traditional & -.578 & .258 & .082 & -1.21 & .06 \\
\hline & $\begin{array}{l}\text { Hybrid- } \\
\text { Simulation }\end{array}$ & $-1.314(*)$ & .259 & .000 & -1.95 & -.68 \\
\hline
\end{tabular}

${ }^{\star}$ The mean difference is significant at the .05 level.

Descriptive statistics for Microsoft PowerPoint revealed that the Hybrid-Simulation group $(\mathrm{M}=4.05)$ outperformed both the Traditional group $(\mathrm{M}=3.90)$ and the Online-Simulation group $(\mathrm{M}=2.86)$ while all three groups had similar standard deviations $(1.64,1.71$, and 1.72 respectively). The ANOVA analysis in Table 6 shows that the p-value (.000) is less than 0.05 , therefore, the results indicate that a statistically significant difference was found between the group means. The Scheffe post hoc test revealed a statistically significant difference when comparing the performance of students in the Online-Simulation group to both the Traditional ( $\mathrm{p}=.000)$ and HybridSimulation $(\mathrm{p}=.000)$ groups (see Table 7$)$; however, there were no statistically significant differences between the Traditional and Hybrid-Simulation groups $(\mathrm{p}=.811)$. 


\begin{tabular}{|l|r|r|r|r|r|}
\hline \multicolumn{7}{|c|}{ Table 6: Microsoft PowerPoint ANOVA } \\
\hline & $\begin{array}{c}\text { Sum of } \\
\text { Squares }\end{array}$ & \multicolumn{1}{|c|}{ df } & Mean Square & F & Sig. \\
\hline Between Groups & 67.576 & 2 & 33.788 & 11.607 & .000 \\
\hline Within Groups & 809.235 & 278 & 2.911 & & \\
\hline Total & 876.811 & 280 & & & \\
\hline
\end{tabular}

\begin{tabular}{|l|l|r|r|r|r|r|}
\hline \multicolumn{7}{|c|}{ Table 7: Microsoft PowerPoint-Multiple Comparisons } \\
\hline Method of Delivery & Method of Delivery & $\begin{array}{c}\text { Mean Differ- } \\
\text { ence }\end{array}$ & \multicolumn{1}{|c|}{ Std. Error } & \multicolumn{1}{c|}{ Sig. } & \multicolumn{2}{c|}{$95 \%$ Confidence Interval } \\
\hline & & $\begin{array}{c}\text { Lower } \\
\text { Bound }\end{array}$ & $\begin{array}{c}\text { Upper } \\
\text { Bound }\end{array}$ & $\begin{array}{c}\text { Lower } \\
\text { Bound }\end{array}$ & Upper Bound & Lower Bound \\
\hline Traditional & Hybrid-Simulation & -.153 & .237 & .811 & -.74 & .43 \\
\hline & Online-Simulation & $1.032\left(^{*}\right)$ & .260 & .000 & .39 & 1.67 \\
\hline Hybrid-Simulation & Traditional & .153 & .237 & .811 & -.43 & .74 \\
\hline Online-Simulation & Traditional & $-1.032\left(^{*}\right)$ & .260 & .000 & -1.67 & 1.83 \\
\hline & Hybrid-Simulation & $-1.186\left(^{*}\right)$ & .261 & .000 & -1.83 & -.39 \\
\hline
\end{tabular}

*The mean difference is significant at the .05 level.

Similarly to Microsoft Word, Excel, and PowerPoint software applications, descriptive statistics for Microsoft Access revealed that the Hybrid-Simulation group $(\mathrm{M}=4.09)$ outperformed both the Traditional group $(\mathrm{M}=3.98)$ and the Online-Simulation group $(\mathrm{M}=2.68)$ while all three groups had similar standard deviations (1.61, 1.70, and 1.84 respectively). The ANOVA analysis in Table 8 shows that the p-value (.000) is less than 0.05 , therefore, the results indicate that a statistically significant difference was found between the group means. The Scheffe post hoc test revealed a statistically significant difference when comparing the performance of students in the fully online group to both the Traditional $(\mathrm{p}=.000)$ and Hybrid-Simulation $(\mathrm{p}=.000)$ groups (see Table 9); however, there were no statistically significant differences between the Traditional and Hybrid groups $(\mathrm{p}=.904)$.

\begin{tabular}{|l|r|r|r|r|r|}
\hline \multicolumn{7}{|c|}{ Table 8: Microsoft Access-ANOVA } \\
\hline & $\begin{array}{c}\text { Sum of } \\
\text { Squares }\end{array}$ & \multicolumn{1}{|c|}{ df } & Mean Square & F & Sig. \\
\hline Between Groups & 98.882 & 2 & 49.441 & 16.928 & .000 \\
\hline Within Groups & 811.929 & 278 & 2.921 & & \\
\hline Total & 910.811 & 280 & & & \\
\hline
\end{tabular}




\begin{tabular}{|c|c|c|c|c|c|c|}
\hline \multicolumn{7}{|c|}{ Table 9: Microsoft Access-Multiple Comparisons } \\
\hline $\begin{array}{l}\text { (I) Method of } \\
\text { Delivery }\end{array}$ & $\begin{array}{l}\text { (J) Method of } \\
\text { Delivery }\end{array}$ & $\begin{array}{c}\text { Mean } \\
\text { Difference }\end{array}$ & Std. Error & Sig. & \multicolumn{2}{|c|}{$95 \%$ Confidence Interval } \\
\hline & & $\begin{array}{l}\text { Lower } \\
\text { Bound }\end{array}$ & $\begin{array}{l}\text { Upper } \\
\text { Bound }\end{array}$ & $\begin{array}{l}\text { Lower } \\
\text { Bound }\end{array}$ & Upper Bound & Lower Bound \\
\hline \multirow[t]{2}{*}{ Traditional } & Hybrid-Simulation & -.106 & .237 & .904 & -.69 & .48 \\
\hline & Online-Simulation & $1.296(*)$ & .260 & .000 & .66 & 1.94 \\
\hline \multirow[t]{2}{*}{ Hybrid-Simulation } & Traditional & .106 & .237 & .904 & -.48 & .69 \\
\hline & Online-Simulation & $1.402(*)$ & .261 & .000 & .76 & 2.05 \\
\hline \multirow[t]{2}{*}{ Online-Simulation } & Traditional & $-1.296(*)$ & .260 & .000 & -1.94 & -.66 \\
\hline & Hybrid-Simulation & $-1.402(*)$ & .261 & .000 & -2.05 & -.76 \\
\hline
\end{tabular}

*The mean difference is significant at the .05 level.

\section{Discussion}

The purpose of this study was to investigate how exposure to computer simulations would affect student performance using different delivery methods for instruction. Findings of this study suggest that the majority of students were able to demonstrate competency of their abilities with over half of the sample population earning a grade average of $\mathrm{C}$ or better on each application.

In assessing the performance of students in the traditional versus the hybrid-simulation format, a significant difference was found with respect to the Microsoft Excel application only. The hybridsimulation group had the best performance with $78 \%$ of the students earning a $\mathrm{C}$ or better compared to $66 \%$ of the traditional group earning the same. Given the nature and complexity of the application, students in the hybrid-simulation group may have benefitted from repeated practice in a controlled environment. Hence, the hybrid-simulation design underscores the importance of lecture reinforced with computer simulation that is a combination of expository instruction and practice modes. These observations answered research question 1- Are there significant differences in student performance when comparing the traditional format with the hybrid method of instruction augmented with computer simulation?

With respect to research question 2 , there were significant differences in student performance when comparing the traditional format with the fully online method of instruction using computer simulation for Microsoft Word, PowerPoint, and Access. Grade averages (the mean) for each application shows that students in the online group taught by simulation approach did not perform as well as their counterparts in the traditional group. A possible explanation is that students in the traditional group benefitted from face-to-face lectures and demonstrations with the professor, a method of instruction omitted from the online-simulation format. The results of this study support the assumption that computer simulations are not as effective when used as a stand-alone instructional method.

In response to research question 3, there were significant differences found between student performance in the hybrid format augmented with computer simulation and the fully online method of instruction using computer simulation for all 4 Microsoft applications-Word, Excel, PowerPoint, and Access. The data showed much higher grade averages for the hybrid-simulation group when compared to the fully online student averages. Such findings support the assertion that the success of computer simulation use ultimately depends on the delivery method for expository instruction. 
There were two major observations from this study:

1. Students overwhelmingly performed better in a mixed modal environment in which faceto-face lectures and demonstrations as well as faculty-student engagement were of paramount importance.

2. Computer simulations are more beneficial when used as reinforcement of concepts covered in lectures, hence, students are able to repeat the simulations until they gain a better understanding and thereby enhancing their learning.

The overall results appear to support the data that computer simulations are most effective when used as a supplement to face-to-face lectures and in hybrid environments (Koh et al., 2010; Mkpanang, 2010; Mosalanejad et al., 2012; Neumann et al., 2011).

\section{Limitations}

Caution is necessary when interpreting the findings as there are two limitations that may impact the current study. While the population sampled were undergraduates from a mid-size public university in the southern part of the United States, it also gives way to the first limitation in focusing on specific demographics and cultures with no comparable data relative to various institutional environments. A similar study conducted in other milieu such as private colleges and larger institutions where student environments differ would enhance the validity of the current findings.

Secondly, the current study assessed student performance without connecting learning and simulation performance. Opponents of simulation use in higher education argue that it is not a valid or reliable predictor of student performance (Teach \& Patel, 2007; Wolfe \& Luethge 2003) and that the presence of educational content in a simulation does not guarantee its efficacy (Koenig et al., 2013); therefore, more research is needed that demonstrates simulation performance equals learning (Anderson \& Lawton, 2009; Xu \& Yang, 2010).

\section{Conclusion}

This study contributes to the scholarship on computer simulation and enables us to offer a nuanced interpretation of differences derived from students' performance in traditional and distance education settings. The study leads to the following conclusions.

1. The hybrid method of instruction augmented with simulation use is much more effective than the traditional and fully online methods of instruction.

2. The traditional face-to-face lecture and demonstration method of instruction is much more effective than the fully online method with computer simulation use only.

3. Learning was achieved through each method of instruction, namely, traditional, hybridsimulation, fully online-simulation.

More studies that quantify the effects of computer simulation on student performance is needed for both traditional and distance learning environments. While innovate and intriguing research is currently ongoing, future research efforts should be focused on the following two areas. First, there is a lack of quantitative data on the effectiveness of computer simulations in distance education settings. Further studies should focus on hybrid as well as fully online environments for comparison purposes. Secondly, further research is needed to determine the degree to which simulation performance equals learning. Deliberate consideration should be given to simulation designs that include goals and objectives, assessment, and instructional strategies.

In summary, the present study indicates that the use of computer simulations in higher education can indeed be a valuable strategy if used as a supplement to traditional face-to-face lectures and 
in a hybrid format, yet, additional research is needed to confirm its value to distance learning environments.

\section{References}

Ackermann, A. (2009). Investigation of learning outcomes for the acquisition and retention of CPR knowledge and skills learned with the use of high-fidelity simulation. Clinical Simulation in Nursing, 5, 213-222.

Alexe, M. (2013). Developing professional English vocabulary through computer based simulated situations. Presented at the $9^{\text {th }}$ International Scientific Conference eLearning and Software for Education, Bucharest, April 25-26, 2013.

Amaral, K., \& Shank, J. (2010). Enhancing student learning and retention with blended class guides. EDUCAUSE Quarterly, 1-20.

Anderson, P., \& Lawton, L. (2009). Business simulations and cognitive learning: Developments, desires, and future directions. Simulation \& Gaming, 40, 193-216.

Asal, V., \& Blake E. (2006). Creating simulations for political science education. Journal of Political Science Education, 2, 1-18.

Bai, X., \& Fusco, D. (2011). Interdisciplinary collaboration through designing 3D simulation case studies. The International Journal of Multimedia \& Its Applications, 3(1), 8-20.

Blake, C., \& Scanlon, E. (2007). Reconsidering simulations in science education at a distance: Features of effective use. Journal of Computer Assisted learning, 23, 491-502.

Bobot, L. (2010). Teaching sales and negotiation with combining computer-based simulation and case discussions. Marketing Education Review, 20(2), 115-122.

Brown, J., Collins, A., \& Duguid, P. (1989). Situated cognition and the culture of learning. Educational Researcher, 18(1), 32-42.

Cameron, B. (2003). Effectiveness of simulation in a hybrid and online networking course. The Quarterly Review of Distance Education, 4(1), 51-55.

Dean, A., \& Webster, L. (2000). Simulation in distance education: Progress towards an evaluation instruction. Distance Education, 21(2), 344-360.

Decker, S., Moore, A., Thal, W., Opton, L., Caballero, S., \& Beasley, M. (2010) Synergistic integration of concept mapping and cause and effect diagramming into simulated experiences. Clinical Simulation in Nursing, 6, 153-159.

Eskrootchi, R., \& Oskrochi, R. (2010). A study of the efficacy of project-based learning integrated with computer-based simulation-STELLA. Educational Technology \& Society, 13(1), 236-245.

Frederking, B. (2005). Simulations and student learning. Journal of Political Science Education, 1, 385393.

Evans, C., \& Fan, F. (2002). Lifelong learning through the virtual university. Campus-Wide Information Systems, 19(4), 127-134.

Granland, R., Bergland, E., \& Eriksson, H. (2000). Designing web-based simulation for learning. Future Generation Computer Systems, 17, 171-185.

Hennessy, S. (2006). Integrating technology into teaching and learning school science: A situated perspective on pedagogical issues in research. Studies in Science Education, 42, 1-48.

Kahn, M., \& Perez, K. (2009). The game of politics simulation: An exploratory study. Journal of Political Science Education, 5, 332-349.

Kardong-Edgren, S., Anderson, M., \& Michaels, J. (2007). Does simulation fidelity improve student test scores? INACSL Online Journal, 3(1), 1-8. 


\section{Use of computer simulation}

Ko, S. \& Rossen, S. (2001). Teaching Online: A Practical Guide. New York: Houghton Mifflin Company, 197.

Koenig, A., Iseli, M., Wainess, R., \& Lee, J. (2013). Assessment methodology for computer-based instructional simulations. Military Medicine, 178, 47-54.

Koh, C., Tan, H., Tan, K., Fang, T., Fong, F., Kan, D., Lye, S., \& Wee, M. (2010). Investigating the effect of 3D simulation-based learning on the motivation and performance of engineering students. Journal of Engineering Education, 237-251.

Mkpanang, J. (2010). Effects of computer-assisted instruction (CAI) with drill and practice on academic achievement of students in physics. Nigerian Journal of Science and Science Education, 8(2), 72-86.

Mosalanejad, L., Shahsavari, S., Sobhanian, S., \& Dastpak, M. (2012). The effect of virtual versus traditional learning in achieving competency-based skills. Turkish Online Journal of Distance Education, 13(2), 69-75.

Muir, T., Allen, J., Rayner, C., \& Cleland, B. (2013). Preparing pre-service teachers for classroom practice in a virtual world: A pilot study using Second Life. Journal of Interactive Media in Education, 3, 1-17.

Neumann, D., Hood, M., \& Neumann, M. (2010). An evaluation of computer-based interactive simulations in the assessment of statistical concepts. International Journal for Technology in Mathematics Education, 19(1), 17-24.

Neumann, D., Neumann, M., \& Hood, M. (2011). Evaluating computer-based simulations, multimedia and animations that help integrate blended learning with lectures in first year statistics. Australasian Journal of Educational Technology, 27(2), 274-289.

Nishikawa, K., \& Jaeger, J. (2011). A computer simulation comparing the incentive structures of dictatorships and democracies. Journal of Political Science Education, 7, 135-142.

Otamendi, F., \& Doncel, L. (2013). Integration and implementation of Web simulators in experimental elearning: An application for capacity auctions. The Turkish Online Journal of Educational Technology, 12(1), 88-101.

Rackaway, C., \& Goertzen, B. (2008). Debating the future: A social security political leadership simulation. Journal of Political Science Education, 4, 330-340.

Rogers, L. (2011). Developing simulations in multi-user virtual environments to enhance healthcare education. British Journal of Educational Technology, 42(4), 608-615.

Rogerson-Revell, P., Nie, M., \& Armellini, A. (2012). An evaluation of the use of voice boards, e-book readers and virtual worlds in a postgraduate distance learning applied linguistics and TESOL programme. Open Learning, 27(2), 103-119.

Rutten, N., Van Jooloingen, W., \& Van der Veen, J. (2012). The learning effects of computer simulations in science education. Computers \& Education, 58(1), 136-153.

Sahin, S. (2006). Computer simulations in science education: Implications for distance education. Turkish Online Journal of Distance Education, 7(4), 1-13.

Sauter, M., Uttal, D., Rapp, D., Downing, M., \& Jona, K. (2013). Getting real: The authenticity of remote labs and simulations for science learning. Distance Education, 34(1), 37-47.

Secomb, J., McKenna, L., \& Smith, C. (2012). The effectiveness of simulation activities on the cognitive abilities of undergraduate third-year nursing students: a randomized control trial. Journal of Clinical Nursing, 21, 3475-3484.

Sharp, H., \& Hall, P. (2000). An interactive multimedia software house simulation for postgraduate software engineers. International Conference in Software Engineering, 688-691.

Shellman, S. (2006). Do simulations enhance student learning? An empirical evaluation of an IR simulation. Journal of Political Science Education, 2, 19-32. 
Teach, R., \& Patel, V. (2007). Assessing participant learning in business simulation. Developments in Business Simulation and Experiential Learning, 34, 76-84.

Udo, M. (2010). Effects of guided-discovery, student-centered demonstration and the expository instructional strategies on students' performances in chemistry. African Research Review, 4(4), 389-398.

Udo, M., \& Etiubon, R. (2011). Computer-based science simulations, guided-discovery and students' performance in chemistry. Modern Applied Science, 5(6), 211-217.

Wheeler, S. (2006). Review essay role-playing games and simulations for international issues courses. Journal of Political Science Education, 2, 331-347.

West, J., \& Veenstra, A. (2012). Cane toad or computer mouse? Real and computer-simulated laboratory exercises in physiology classes. Australian Journal of Education, 56(1), 56-67.

Wolfe, J. \& Luethge, D. (2003). The impact of involvement on performance in business simulations: An examination of Goosen's "know little" decision-making thesis. Journal of Education for Business, 79, $69-74$.

Xu, Y., \& Yang, Y. (2010). Student learning in business simulations: An empirical investigation. Journal of Education for Business, 85, 223-228.

\section{Biographies}

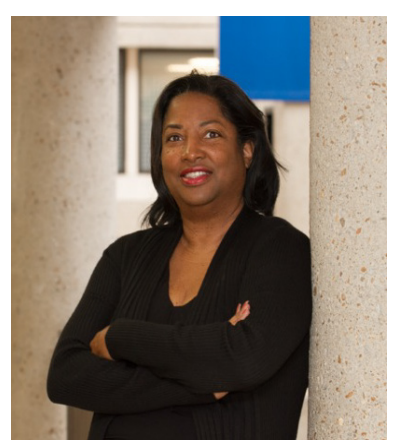

Dr. Retta Guy has an Ed.D. in Curriculum and Instruction with emphasis in Instructional Systems Design from the University of Kentucky. She currently serves as Interim Associate Dean in the College of Business and is a tenured Professor in the Department of Business Information Systems at Tennessee State University in Nashville. As an active author, Dr. Guy's scholarly publications include an authored book entitled "The Digitally Disinterested," two edited books entitled "The Evolution of Mobile Teaching and Learning" and "Mobile Learning: Pilot Projects and Initiatives," 6 book chapters, 25+ articles, and 10 refereed proceedings to date. Dr. Guy's intellectual interests include the use of digital technologies to augment teaching and learning, instructional design and assessment, as well as distance learning with specific emphasis in hybrid, online and mobile teaching and learning.

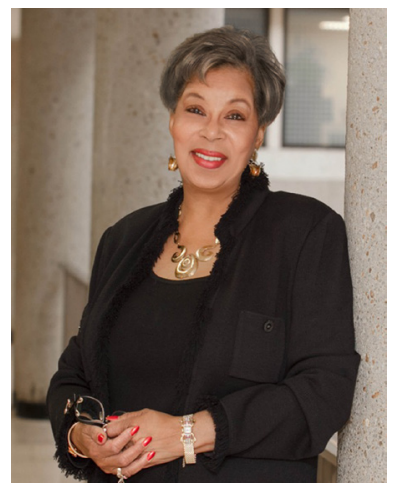

Dr. Millicent Lownes-Jackson is Dean of the College of Business at Tennessee State University. She is a small business specialist, author of 15 books, an entrepreneur, newspaper columnist, researcher, certified small business coach, and a tenured Professor of Management. Dr. Lownes-Jackson's educational background includes a Bachelor of Business Administration Degree from Fisk University. She also has a Master of Business Administration Degree and a Doctor of Philosophy Degree, both of which were conferred by Vanderbilt University. Dr. Lownes-Jackson has many research articles, publications and talk show appearances to her credit. She has been featured in numerous stories including articles appearing in Black Enterprise magazine, Contempora magazine, the Tennessee Tribune and the Urban Journal. 